Original Paper http://ajol.info/index.php/ijbcs http://indexmedicus.afro.who.int

\title{
Cytological, foliar epidermal and pollen grain studies in relation to ploidy levels in four species of Physalis L. (Solanaceae) from Nigeria
}

\author{
Sekinat Okikiola AZEEZ*, Julius Olaoye FALUYI and Mathew OZIEGBE \\ Department of Botany, Faculty of Science, Obafemi Awolowo University, Nigeria. \\ *Corresponding author; E-mail: sekinatokiki@gmail.com
}

\begin{abstract}
The relationship in the ploidy levels, pollen grain and epidermal parameters among four Physalis species ( $P$. angulata Linn., P. peruviana Linn., P. micrantha Link. and P. pubescens Linn) present in Nigeria was investigated from meiotic chromosome, foliar epidermal and pollen grain studies using standard techniques. The study revealed that $P$. angulata has chromosome number of $2 n=4 x=48$ as against $2 n=2 x=24$ recorded in each of the other species. The chromosomes of all the four Physalis species studied were well paired at pachynema as ring II or rod II with two simultaneous cytokineses observed in all. Tetrad pollens were observed in an accession of $P$. micrantha. Significantly higher pollen diameter, guard cell area and stomata Index were recorded in $P$. angulata when compared with the diploid species investigated. The results indicated that the tetraploid nature of $P$. angulata correlates with its higher guard cell area and pollen grain diameter respectively.
\end{abstract}

(C) 2019 International Formulae Group. All rights reserved

Keywords: Chromosome association, tetraploid, diploid, pollen grains, tricolporate, stomata.

\section{INTRODUCTION}

Four Physalis (P. angulata, $P$. peruviana, $P$. micrantha and $P$. pubescens) species have been reported in West Africa and they are all represented in Nigeria (Azeez and Faluyi, 2018). Husaini and Iwo (1990) and Wahua and Sam (2013) reported two different chromosome numbers of $2 \mathrm{n}=4 \mathrm{x}=48$ and $2 \mathrm{n}=2 \mathrm{x}=24$ respectively for $P$. angulata in Nigeria. Burkill (2000) documented $2 \mathrm{n}=4 \mathrm{x}=48$ for West African $P$. peruviana whereas $2 n=2 x=24$ was observed in the Nigerian population for this species (Olorode et al., 2013). However, there is no known record of chromosome count for $P$. pubescens in Nigeria.

Many researchers have used stomatal size and pollen grain diameter which were described to be simple and less stressful methods of determining the ploidy levels in many plants. It has been reported that as ploidy level increases, the stomatal size as well as pollen diameter increases (Jaochimiak and Grabowska-Jaochimiak, 2000; Kadota and Niimi, 2002; Chen et al., 2009; Ye et al., 2010; Ghasemi et al., 2014). 
Some Physalis species have been reported to have food value or one medicinal use or the other such as antidiabetic and antioxidative activities (Burkill, 2000; Oladele et al., 2013). In Nigeria, $P$. angulata is a potential vegetable; it served as food for the people of Northener Nigeria in 1972/1973 during the lean year (Burkill, 2000). Considering the economic importance of Physalis species, it is very crucial to ascertain the chromosome number/ploidy level(s) of these species in Nigeria as a result of the lack of consensus on chromosome number of $P$. angulata and $P$. peruviana in Nigeria so as to prevent misidentification. Hence, this study investigated the relationship in chromosome count/ ploidy level, pollen grain diameter and guard cell area among four Physalis species in Nigeria.

\section{MATERIALS AND METHODS}

Herbarium studies were carried out at the IFE Herbarium and the Flora of West Tropical Africa by Hutchinson and Dalziel (1963) was consulted to provide information on the species identification and distribution. Physalis species were collected from different locations in South Western Nigeria (Table 1) and were identified, planted and nursed to maturity. Seeds were recovered from matured fruits from each species and planted separately. The seedlings from each species were transplanted into five 11-litre plastic buckets filled with top soil for each species.

\section{Meiotic chromosome study}

The young flower buds were harvested from each of species for meiotic chromosome study between 9.00 am and $12.00 \mathrm{pm}$ when the cell activities were believed to be at the peak and stored in 1:3 Acetic acid: alcohol. The anthers were later removed, squashed and stained in FLP Orcein by the squash technique method according to Azeez and Faluyi (2018). The Pollen Mother Cells were examined and scored for chromosome associations. Good meiotic chromosome spreads were photographed at $\mathrm{x} 1000$ under $\mathrm{BK}$ series system microscope.

\section{Pollen grain study}

Fresh pollen grains from each species were collected, stored in $70 \%$ ethanol and subjected to acetolysis according to Azeez and Folorunsho (2014). Photomicrographs of the pollen grains were documented at $\mathrm{x} 400$ phase contrast and oil immersion illumination under BK series system microscope (BKSS microscope) attached with Digital Camera for Microscope (DCM510, CMOS chips). The diameters of the acetolysed pollens were measured at $\mathrm{x} 400$ and their morphologies were described. The pollen fertility was estimated using the method of Bolaji and Nwokeocha (2013).

\section{Foliar epidermal study}

The epidermal peels for each of the Physalis species were obtained according to techniques of Ibrahim and Ayodele (2013) and Nwokeocha (2015). The epidermal peels were stained with Safranin ' $O$ ' for 3-5 minutes, rinsed in distilled water and then mounted in $25 \%$ glycerine for examination. Photomicrographs of the epidermis of each of the species were taken for both adaxial and abaxial surfaces at $\mathrm{x} 1000$ under $\mathrm{BK}$ series system microscope attached with a digital camera (DCM 510, CMOS chips). The stomata type, the stomata density per $\mathrm{mm}^{2}$, the Stomata Index (I), trichome type and Trichome Index (T) were calculated according to the method of Wahua and Sam (2013) and the guard cell area was estimated for the two leaf surfaces using standard method.

\section{Statistical analysis}

The means and standard errors were calculated for the quantitative data collected. One-way ANOVA was employed and Duncan multiple range test was carried out to separate the means. 
Table 1: Germplasm Sources Used for the Studies.

\begin{tabular}{|c|c|c|}
\hline Species Code & Location & Longitudes and Latitudes \\
\hline PMR 1201 & $\begin{array}{l}\text { Dump site at Odoje Ojubo on Ogbomoso-Ajawa } \\
\text { Road, Ogbomosho, Oyo State. }\end{array}$ & $8^{\circ} 08^{\prime} 00.00^{\prime} \mathrm{N} 4^{\circ} 15^{\prime} 00.00^{\prime \prime} \mathrm{E}$ \\
\hline PMR 1301 & Along the road at Omuo-Ekiti, Ekiti State. & $7^{\circ} 45^{\prime} 46.85^{\prime} \mathrm{N} 5^{\circ} 43^{\prime} 28.98^{\prime \prime} \mathrm{E}$ \\
\hline PMR 1401 & Fallow land at New Market, OAU, Ile-Ife & $7^{\circ} 29^{\prime} 12.07^{\prime \prime} \mathrm{N} 4^{\circ} 29^{\prime} 35.42^{\prime \prime} \mathrm{E}$ \\
\hline PMR 1402 & Along Road 7, Ile-Ife & $7^{\circ} 29^{\prime} 12.07^{\prime} \mathrm{N} 4^{\circ} 29^{\prime} 35.42^{\prime \prime} \mathrm{E}$ \\
\hline PAG 1302 & Dump site around Pottery Museum, Moore, Ile-Ife & $7^{\circ} 35^{\prime} 25.84^{\prime \prime} \mathrm{N} 4^{\circ} 44^{\prime} 00.81^{\prime \prime} \mathrm{E}$ \\
\hline PAG 1202 & $\begin{array}{l}\text { Fallow land around Music Department, OAU, Ile- } \\
\text { Ife }\end{array}$ & $7^{\circ} 29^{\prime} 12.07^{\prime} \mathrm{N} 4^{\circ} 29^{\prime} 35.42^{\prime \prime} \mathrm{E}$ \\
\hline PAG 1203 & Along the road, Oranfe area, Ile-Ife & $7^{\circ} 35^{\prime} 25.84^{\prime \prime} \mathrm{N} 4^{\circ} 44^{\prime} 00.81^{\prime \prime} \mathrm{E}$ \\
\hline PPR 1204 & Dump site around Town Hall, Iloko-Ijesa & $7^{\circ} 39^{\prime} 08.48^{\prime \prime} \mathrm{N} 4^{\circ} 49^{\prime} 24.78^{\prime \prime} \mathrm{E}$ \\
\hline PPR 1204 & Fallow land around Pottery Museum, Moore, Ile-Ife & $7^{\circ} 35^{\prime} 25.84^{\prime \prime} \mathrm{N} 4^{\circ} 44^{\prime} 00.81^{\prime \prime} \mathrm{E}$ \\
\hline PPR1303 & Dump site at Akinyele LGA, Ibadan & $7^{\circ} 31^{\prime} 49.87^{\prime \prime} \mathrm{N} 3^{\circ} 54^{\prime} 39.20^{\prime \prime} \mathrm{E}$ \\
\hline PPB 1206 & Around Music Department, OAU, Ile-Ife & $7^{\circ} 29^{\prime} 12.07^{\prime \prime} \mathrm{N} 4^{\circ}$ 29'35.42”E \\
\hline PPB 1207 & Dump site around Pottery Museum, Moore, Ile-Ife & $7^{\circ} 35^{\prime} 25.84^{\prime \prime} \mathrm{N} 4^{\circ} 44^{\prime} 00.81^{\prime \prime} \mathrm{E}$ \\
\hline PPB 1304 & Dump site at Akinyele LGA, Ibadan & $7^{\circ} 31^{\prime} 49.87^{\prime \prime} \mathrm{N} 3^{\circ} 54^{\prime} 39.20^{\prime \prime} \mathrm{E}$ \\
\hline
\end{tabular}

\section{RESULTS}

\section{Meiotic chromosome study}

The meiotic chromosome studies revealed that $P$. angulata has a chromosome number of $2 \mathrm{n}=4 \mathrm{x}=48$ (Figure1a-b) while $P$. micrantha, $P$. peruviana and $P$. pubescens have the same chromosome number of $2 \mathrm{n}=2 \mathrm{x}=24$ (Figure $1 \mathrm{c}-\mathrm{h}$ ). The chromosomes of all the four Physalis species were well paired at pachynema and presented as ring II or rod II at diakinesis. Two simultaneous cytokineses were observed in all the four Physalis species. There was no abnormality observed in all the stages of meiotic cell division. The events of cell division were asynchronous in all the four Physalis species, though these events were synchronous in each anther. This is evident from the fact that the pollen mother cells found together were at the same stage of cell division.

\section{Pollen grain study}

All the pollen grains observed in the four Physalis species studied were tricolporate, small to medium in size with polar axis ranging between $23.94 \mu \mathrm{m}$ in $P$. peruviana to $30.73 \mu \mathrm{m}$ in $P$. angulata (Figure 2a-d). The shapes of the pollen grains were largely prolate, spheroidal or oblate spheroidal. The pollens were monads except in one accession (PMC 1301) of P. micrantha in which the pollens occurred mostly as tetrads (Figure 2d and Table 2). In addition, triads and dyads were present while monads were very rare in this accession. Physalis angulata has significantly larger pollen grains with equatorial diameter of $30.73 \mu \mathrm{m}$. The equatorial diameter of the other three diploid species was between $24.06 \mu \mathrm{m}$ in $P$. peruviana and $25.04 \mu \mathrm{m}$ in $P$. pubescens. Both the polar axis and equatorial diameter of $P$. angulata pollen grains were significantly higher than those of the other three species studied (Table 2).

\section{Foliar epidermal study}

The most predominant stomata types observed in the Physalis species studied were 
anomocytic and anisocytic though tetracytic stomata were observed occasionally in the four species, with stomata generally closed (Figure 3a-h). Multicellular trichomes were observed in all the four species. The highest trichome index of $0.1 \%$ was recorded in $P$. peruviana. Physalis angulata has the highest stomata index and largest guard cell area (Table 3). There was no significant difference in the stomata indices among the diploid species. In this study, higher guard cell area was recorded in the adaxial surfaces than adaxial surfaces in $P$. angulata and $P$. peruviana. In contrast, it was higher on the abaxial surface of $P$. micrantha though no significance difference was observed on the two surfaces of $P$. pubescens.
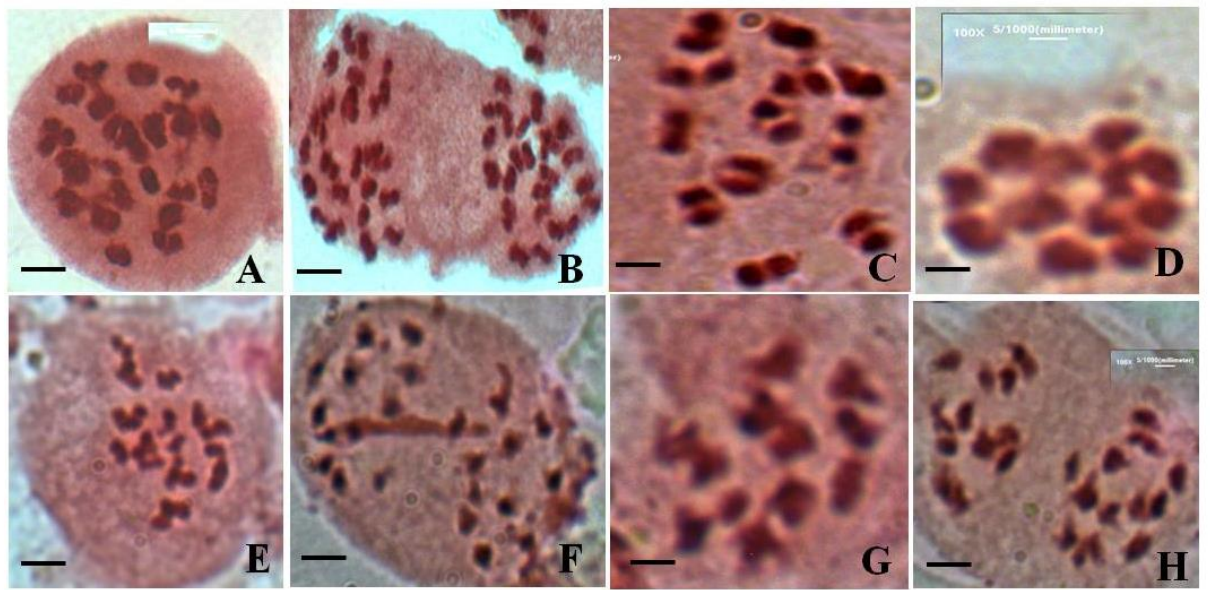

Figure 1a-h: Stages of meiotic cell divisions in the Four Physalis species studied

A. Late diakinesis in P. angulata showing $24 \mathrm{II}$

B. Metaphase II in P. angulata showing $\mathrm{n}=24$ at each pole

C. Diakinesis in P. pubescens showing 12II

D. Metaphase I $P$. pubescens showing $12 \mathrm{II}$

E. Late diakinesis in P. micrantha showing 12II

F. Metaphase II in P. micrantha showing $\mathrm{n}=12$ at each pole

G. Metaphase I in P. peruviana showing 12II

H. Metaphase II in P. peruviana showing $\mathrm{n}=12$ at each pole . Scale bar $=3 \mu \mathrm{m}$

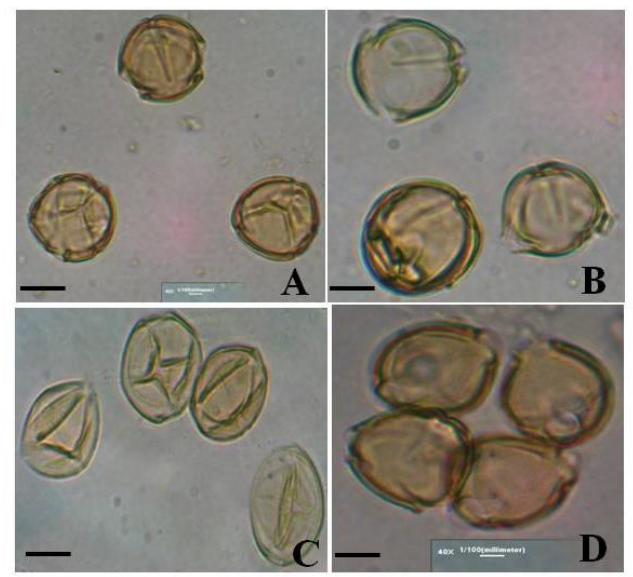

Figure 2a-d: Pollen grains of the four Physalis species studied. a-c Monad pollen in $P$. angulata, $P$. pubescens and P. peruviana d. Tetrad pollen in P. micrantha Scale bar $=4 \mu \mathrm{m}$ 

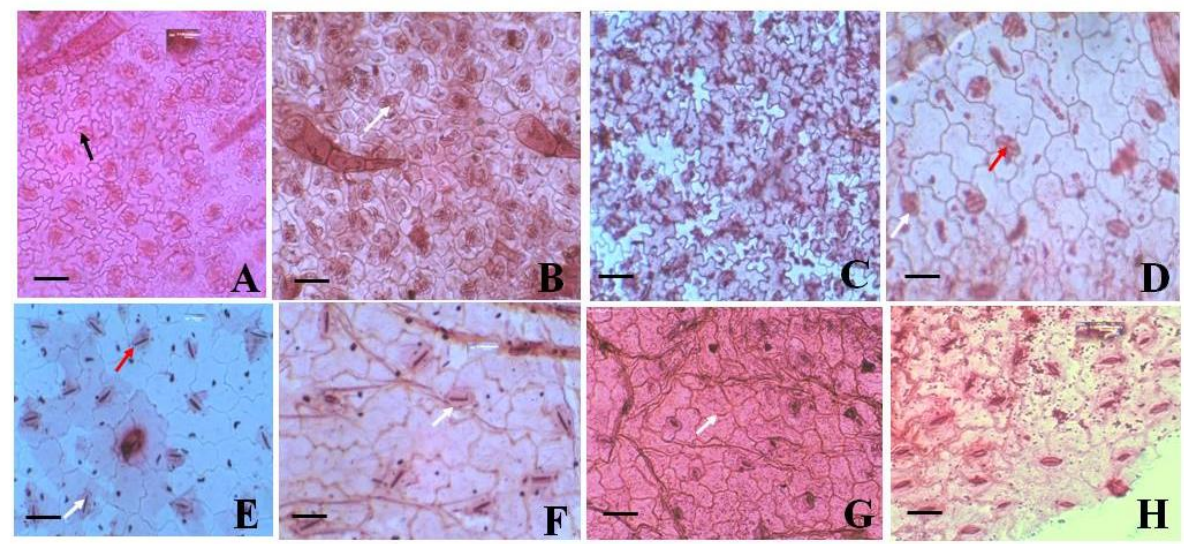

Figure 3a-h: Foliar epidermal features of the four Physalis species studied.
A. Abaxial of P. peruviana
B. Adaxial of P. peruviana
C. Abaxial of $P$. pubescens
D. Adaxial of P. pubescens
E. Abaxial of $P$. angulata
F. Adaxial of P. angulata
G. Abaxial of P. micrantha
H. $\quad$ Adaxial of P. micrantha

*Black arrows indicate anomocytic stomata, white arrows indicate anisocytic, red arrows indicate tetracytic stomata. Scale $\mathrm{bar}=4 \mu \mathrm{m}$

Table 2: Pollen grain parameters in the Physalis species studied.

\begin{tabular}{lcccc}
\hline Pollen Characters & $\begin{array}{l}\text { Physalis } \\
\text { peruviana }\end{array}$ & $\begin{array}{l}\text { Physalis } \\
\text { micrantha }\end{array}$ & $\begin{array}{l}\text { Physalis } \\
\text { pubescens }\end{array}$ & Physalis angulata \\
\hline $\begin{array}{l}\text { Polar axis }(\mu \mathrm{m}) \\
\text { Equatorial Diameter }\end{array}$ & $23.94^{\mathrm{a}}$ & $24.43^{\mathrm{ab}}$ & $25.40^{\mathrm{b}}$ & $30.73^{\mathrm{c}}$ \\
$(\mu \mathrm{m})$ & $24.06^{\mathrm{a}}$ & $24.56^{\mathrm{ab}}$ & $25.40^{\mathrm{b}}$ & $30.73^{\mathrm{c}}$ \\
Colpi $(\mu \mathrm{m})$ & $22.57^{\mathrm{a}}$ & $22.57^{\mathrm{a}}$ & $22.81^{\mathrm{b}}$ & $22.81^{\mathrm{b}}$ \\
Ora $(\mu \mathrm{m})$ & $5.82^{\mathrm{c}}$ & $6.88^{\mathrm{d}}$ & $4.54^{\mathrm{b}}$ & $0.00^{\mathrm{a}}$ \\
Exine $(\mu \mathrm{m})$ & $2.28^{\mathrm{d}}$ & $1.90^{\mathrm{b}}$ & $2.33^{\mathrm{c}}$ & $1.37^{\mathrm{a}}$ \\
Exine Pattern & Finely & Reticulate & Reticulate & Finely reticulate \\
& reticulate & & & \\
Shape & Prolate & Prolate & Oblate & Oblate-or Prolate \\
& spheroidal & spheroidal & spheroidal & spheroidal \\
Pollen Stainability $(\%)$ & 92.30 & 80.60 & 89.60 & 89.30 \\
\hline
\end{tabular}

*Means within each row with different superscripts are significantly different at $\mathrm{P}<0.05$

Table 3: Epidermal features of the Physalis species studied.

\begin{tabular}{cccc}
\hline Species & Trichome Index $(\%)$ & Stomata Index $(\%)$ & Guard Cell Area $\left(\mu \mathbf{m}^{2}\right)$ \\
\hline P. micrantha & $0.02^{\mathrm{c}}$ & $0.24^{\mathrm{b}}$ & $2.17^{\mathrm{d}}$ \\
P. pubescens & $0.04^{\mathrm{b}}$ & $0.25^{\mathrm{b}}$ & $2.75^{\mathrm{c}}$ \\
P. peruviana & $0.10^{\mathrm{a}}$ & $0.23^{\mathrm{b}}$ & $3.03^{\mathrm{b}}$ \\
P. angulata & $0.03^{\mathrm{b}}$ & $0.27^{\mathrm{a}}$ & $6.23^{\mathrm{a}}$ \\
\hline
\end{tabular}

*Means within each row with different superscripts are significantly different at $\mathrm{P}<0.05$. 


\section{DISCUSSION}

The pairing pattern for each Physalis species studied was regular. Ganapathi et al. (1991) reported regular pairing pattern for $P$. angulata, $P$. peruviana $P$. minima and $P$. pubescens in India. The asynchronous events of cell division that were observed in this study might be as a result of different rates of development observed among the five anthers in each of the flower bud of Physalis species studied because the anthers do not dehisce at the same time. About 2-3 days is usually required for all the anthers to dehisce. This observation corroborates the report of Menzel (1951). The chromosome number of $2 \mathrm{n}=48$ for $P$. angulata observed in this study is in agreement with previous studies (Menzel, 1951; Husaini and Iwo, 1990; Olorode et al., 2013). However, Wahua and Sam (2013) reported $2 \mathrm{n}=24$ for $P$. angulata in Nigeria. Menzel (1951) stated that the report of $2 n=24$ for $P$. angulata can be considered as a case of misidentification. Burkill (2000) documented $2 \mathrm{n}=48$ for $P$. peruviana whereas Rodriquez and Bueno (2006) recorded chromosome counts of $2 \mathrm{n}=24,2 \mathrm{n}=32$ and $2 \mathrm{n}=48$ for $P$. peruviana. The chromosome number of $2 \mathrm{n}=24$ was reported for $P$. peruviana in this study corroborates the report of Olorode et al. (2013). Menzel (1951) suggested that $P$. peruviana may possibly have more than one chromosome number. It has been reported that this species is stable and delimited in its place of origin which seemed to be tetraploid in that same population. The report of $2 \mathrm{n}=24$ for $P$. micrantha in this present study supports the findings of Wahua and Sam (2013).

The pollen morphology observed in this study is in agreement with previous report for the genus Physalis (Perveen and Qaizer, 2007). Remarkably, tetrad pollen grains were observed only in an accession of $P$. micrantha out of all the accessions of the four species investigated. Physalis angulata, a tetraploid, has the largest pollen grains. An increase in pollen diameter as ploidy level increases has been documented by many researchers in angiosperms (Venessa et al., 2004; Jones and
Reed, 2007; Zlesak, 2009). The increase in ploidy level in Iris was associated with a significant increase in the length of stomata guard cells and the pollen grain diameter when compared with Iris species with lower ploidy levels of chromosome (Ghasemi et al., 2014). The higher pollen size as well as wider guard cell area observed in $P$. angulata is as a result of gigas effects which are characteristics of polyploids. In addition, chromosome number and bivalent pairing in $P$. angulata showed that the species is a tetraploid with a diploid like behaviour $(2 n=4 x=48)$.

Amphistomatic leaves were observed in all the four Physalis species in this study which is in agreement with the previous studies (Savulescu and Hoza, 2011 and Wahua and Sam, 2013). The stomata indices observed in this study were significantly higher than earlier reports. Anomocytic stomata observed in this study corroborates previous findings in $P$. micrantha, $P$. peruviana and $P$. angulata (Savulescu and Hoza, 2011; Thepsithar and Thongpukdee, 2013; Wahua and Sam, 2013). Simple uniseriate multicellular trichomes were observed in all the species studied, with the exception of the adaxial surface of $P$. angulata where unicellular uniseriate and simple unicellular glandular trichomes were observed. Wahua and Sam (2013) also reported uniseriate trichomes in these Physalis species. Differences in the width of stomata guard cells recorded on adaxial and abaxial surfaces of Physalis species in this present study have also been documented in some species of Corchorus studied by Maity and Datta (2011).

Physalis angulata has the highest guard cell area. Jones and Reed (2007) observed that stomatal guard lengths in Hydragea macrophylla ssp. macrophylla diploid cultivars were lesser than those of triploid cutivars. This study showed that $P$. angulata which is characterized by the largest guard cell area has the highest Stomata Index. According to khazaei et al. (2010), higher 
stomatal frequency as well as lower stomata length and width were observed in diploid wheat. However, as the ploidy level increases, the stomatal frequency decreases while the stomatal size increases. In addition, the same trend was noted by Venkatesh et al. (2014) in two mulberry varieties. Also, Wang and Lei (2012), reported significantly larger stomata size and lower stomata density in tetraploids when compared with the diploids in Clivia miniata Regel. According to the findings of Hansen et al. (2007), polyploidy occasionally results in an increase in plant size which is probably due to reduction in the number of cell divisions during development. Beaulieu et al. (2008) reported a close relationship between genome size and guard cell length as well as epidermal cell area; while inverse relationship was reported between genome size and stomata density. This shows that the traits are undergoing correlated evolution with the genome size and stomata density in the angiosperm (Beaulieu et al., 2008). Joachimiak and Grabowska-Joachimiak (2000) stated that the measurement of the stomata length is useful for proper taxonomic identification as well as determining the ploidy level in morphologically non distinct species belonging to closely related pairs of taxa in Phleum.

\section{Conclusion}

The relationship in chromosome counts, ploidy level, pollen grain diameter and stomatal guard cell area among four Physalis species in Nigeria has been investigated. It was confirmed in this present study that $P$. angulata is a tetraploid with $2 \mathrm{n}=4 \mathrm{x}=48$ while $P$. micrantha, $P$. pubescens and $P$. peruviana are diploids with $2 \mathrm{n}=2 \mathrm{x}=24$. Tetrad pollen grains were observed in an accession of $P$. micrantha. The pollen grain diameter and guard cell were significantly higher in the tetraploid when compared with the diploid species. It can therefore be concluded that the tetraploid nature of $P$. angulata is responsible for the highest pollen diameter as well as largest guard cell area observed in this study.

\section{COMPETING INTERESTS}

The authors declare that they have no competing interests.

\section{AUTHORS' CONTRIBUTIONS}

The first author carried out pollen grain and foliar epidermal studies. The idea of the work came from second author, supervised by him and he took all the photomicrographs in the manuscript. The chromosome study aspect of the work was jointly carried out by all the authors and they jointly prepared the manuscript.

\section{ACKNOWLEDGEMENTS}

Special thanks go to Dr A. J. Akinloye for his technical support.

\section{REFERENCES}

Azeez SO, Faluyi JO. 2018. Hybridization in four Nigeria Physalis (Linn.) species. Notulae Scientia Biologicae, 10(2): 205210. DOI: $10.25835 / \mathrm{nsb} 10210241$

Azeez SO, Folorunso AE. 2014. Phenology and pollen studies of some species of Annonaceae in Nigeria. Ife journal of Science, 16(2): 171-179.

Beaulieu JM, Leitch IJ, Patel SI, Pendharkar A, Knight CA. 2008. Genome size is a strong predictor of cell size and stomatal density in angiosperms. New Phytologist, 179: 975-986. DOI: $10.1111 / J .1469$ 8137.2008.02528x.

Bolaji AO, Nwokeocha CC. 2013. Issues concerning reproductive isolation in a rice hybrid swarm involving Oryza sativa Linn. O. longistaminata A Chev. Et Roehrs and Oryza glaberrima Steud. Located in Jebba Nigeria. Int. J. Biol. Chem. Sci., 7(5): 2040-2049. DOI: http://dx, doi.org/10.4314/ijbcs.v7.5.21

Burkill HM. 2000. The Useful Plants of West Tropical Africa ( $2^{\text {nd }}$ edn). Royal Botanic Gardens: Kew, Richmond, United Kingdom.

Chen G, Sun W, Sun H. 2009. Morphological characteristics of leaf epidermis and size variation of leaf, flower and fruit in 
different ploidy levels in Buddleja macrostachya (Buddlejaceae). Journal of Systematics and Evolution, 47(3): 231236.

DOI: https://doi.org/10.1111/J.17596831.2009.00026.x

Ganapathi A, Sudhakaran S, Kulothungan S. 1991. The diploid taxon in Indian natural populations of Physalis L. and its taxonomic significance. Cytologia, 56: 283-288.

Ghasemi SJ, Rabies V, Soleyman IA, Khalighi A. 2014. Investigation of the morphocytological traits and ploidy level in Iris species of Iranian native in Zanjan Province. Journal of Biodiversity and Environmental Science, 5(1): 72-81.

Hansen DL, Lambertini C, Jampeetong A. 2007. Clone-specific differences in Phragmites australis: effects of ploidy level and geographic origin. Aquatic Botany, 86(3): 269-279. DOI: https://doi.org/10.1016/J.aquabot.2006.1 1.05

Husaini SWH, Iwo GA. 1990. Cytomorphological studies in some weedy species of the family Solanaceae from Jos Plateau, Nigeria. Feddes Repertorium, 101(1-2): 41-47. DOI: https://doi.org/10.1002/fedr.1990101010 3

Hutchinson J, Dalziel JM. 1963. Flora of West Tropical Africa. White Fnar Press: London.

Ibrahim JA, Ayodele AE. 2013. Taxonomic significance of leaf epidermal characters of the family Loranthaceae in Nigeria. World Applied Science Journal, 24(9): 1172-1179.

DOI: 10.5829/idoci.wasj.2013.24.09.13125

Joachimiak A, Grabowska-Joachimiak A. 2000. Stomatal cell length and ploidy level in four taxa belonging to the Phleum sect. Phleum. Acta Biological Cracoviensia, 42(1):103-107.

Jones KD, Reed SM. 2007. Analysis of ploidy level and its effects on guard cell length, pollen diameter and fertility in
Hydrangea macrophylla. HortScience, 42(3): 483-488.

Kadota M, Niimi Y. 2002. In vitro induction of tetraploid plants from a diploid Japanese pear cultivar (Pyrus pyrifolia N. cv. Hosui). Plant Cell Reports, 21(3): 282-286. DOI: $10.1007 / \mathrm{s}$ 00299-0020509-1

Khazaei H, Monneveux P, Hongbo S, Mohammandy S. 2010. Variation for stomatal characteristics and water use efficiency among diploid, tetraploid and hexaploid Iranian wheat landraces. Genetic Resources and Crop Evolution, 57: 307-314.

Maity S, Datta AK. 2011. Stomata parameters in nine species of Corchorus (Tiliaceae). Int. J. Biol. Chem. Sci., 5(4): 1354-1304. DOI: http:/dx.doi.org/10.4314/ijbcs.v5i4.2

Menzel MY. 1951. The cytotaxonomy and genetics of Physalis. Proceedings of the American Philosophical Society, 95(2): 132-183.

DOI: https://www.jstor.org/stable/314331

Nwokeocha CC. 2015. Botanical indices of ploidy levels in some African accessions of Oryza punctata Kotschy es Steud. Int. J. Biol. Chem. Sci., 9(1): 35-47. DOI: http://dx.doi.org/10.4314/ijbcs.v9i1.4

Oladele GM, Ode OJ, Akande MG, Ogunbodede MA, Simon MK. 2013. Effect of Ethanolic Root Extract of Physalis angulata on alloxon induced diabetic rats. International Journal of Applied Pharmaceutical Sciences and Biological Sciences, 2(2): 095-100.

Olorode O, Olayanju S, Garba A. 2013. Physalis (Solanaceae) in Nigeria. Ife Journal of Science, 15(1): 101-109.

Perveen A, Qaiser M. 2007. Pollen morphology of family Solanaceae from Pakistan. Pakistan Journal of Botany, 39(7): 2243-2256.

Rodriguez NC, Bueno ML. 2006. Study of the cytogenetic diversity of Physalis peruviana L. (Solanaceae). Acta Biologica Colombiana, 11(2): 75-85. 
Savulescu E, Hoza G. 2011. Anatomy study of Physalis peruviana L. species (Solanaceae). Horticulturae, 55: 643646.

Thepsitha C, Thongpukdee A. 2013. Comparative micro-morphology, anatomy and architecture of leaf of Physalis. International Journal of Bioengineering and Life Sciences, 7(8):806-810.

Vanessa MO, Eliana RF, Pedro MM, Marcos NA. 2004. Chromosomal and morphological studies of diploid and polyploidy cytotypes of Stevia rebaudiana (Bertoni) Bertoni (Eupatoriere, Asteraceae). Genetics and Molecular Biology, 27(2): 215-222. DOI: http://dx.doi.org/10.1590/s141547572004000200015.

Venkatesh KH, Shivaswamy S, Munirajappa. 2014. Cytomorphological studies of two mulberry varieties. African Journal of Biotechnology, 13(2): 2203-2207. DOI: 10.5897/AJB2014.13623.

Wahua C, Sam SM. 2013. Comparative chemotaxonomic investigations on
Physalis angulata Linn. and Physalis micrantha Linn. (Solanaceae). Asian journal of Applied Sciences, 1(5): 220228.

Wang C, Lei J. 2012. In vitro induction of teraploids from immature embryos through colchicine treatments in Cliviaminiata Regel. African Journal of Agricultural Research, 7(25): 37123718. DOI: 10.5897/AJAR11.2343

Ye YM, Tong J, Shi XP, Yuan W, Li GR. 2010. Morphological and cytological studies of diploid and colchicine-induced tetraploid lines of crape myrtle (Lagerstroemia indica L.). Scientia Horticulturae, 124(1): 95-101. DOI: https://doi.org/10.1016/j.scienta.2009.12. 016.

Zlesak DC. 2009. Pollen and guard cell length as predictors of ploidy in diverse rose cultivars, species and breeding lines. Floriculture and Ornamental Biotechnology, 3(1): 53-70. 